\title{
Viability of Lactobacillus casei in chocolate flan and its survival to simulated gastrointestinal conditions
}

\author{
Viabilidade de Lactobacillus casei em flan de chocolate e sua \\ sobrevivência em condições gastrintestinais simuladas
}

\author{
Alisson Santana da Silva ${ }^{1}$; Edson Renato Honjoya ${ }^{2}$; Osney Massami Inay ${ }^{3}$; \\ Marcela de Rezende Costa ${ }^{4}$; Cínthia Hoch Batista de Souza ${ }^{5}$; Elsa Helena Walter \\ de Santana ${ }^{5}$; Hélio Hiroshi Suguimoto ${ }^{5}$, Lina Casale Aragon-Alegro ${ }^{5 *}$
}

\begin{abstract}
The aim of this work was to verify the viability of Lactobacillus casei in chocolate flan as well as its survival under simulated human gastrointestinal conditions. After 1 and 15 days of manufacture, the dessert was evaluated for $L$. casei population and subsequently submitted to acidic solution for 30, 60, 90 and $120 \mathrm{~min}$ and to bile salts solution for $150 \mathrm{~min}$. After each time, L. casei population was evaluated. The results were evaluated by variance analysis (ANOVA) and Tukey's test. The population of $L$. casei in the flan was above $10^{\circ} \mathrm{CFU} / \mathrm{g}$ during the shelf life, whose value is above the limit established for a probiotic food by the Brazilian legislation. $L$. casei was relatively resistant to the simulated gastrointestinal conditions tested in this study, once the population reduced during the in vitro tests but remained above $10^{6} \mathrm{CFU} / \mathrm{g}$. Chocolate flan showed to be an excellent food for addition of probiotic microorganisms, especially $L$. casei, once it was observed high populations in the product even after in vitro resistance tests simulating the human digestive process.
\end{abstract}

Key words: Dairy desserts, probiotic microorganisms, shelf life

\section{Resumo}

Neste trabalho, verificou-se a viabilidade de Lactobacillus casei em flan de chocolate, além de sua sobrevivência em condições que simulam o trato gastrointestinal humano. Após 1 e 15 dias da produção, a população de $L$. casei presente na sobremesa foi avaliada, e o flan foi submetido, em seguida, a uma solução ácida, durante 30, 60, 90 e 120 minutos, e a uma solução de sais biliares, por um período de 150 minutos. Após cada um desses tempos, a população de $L$. casei foi observada. Os resultados foram avaliados por meio de análise de variância (ANOVA) e teste de Tukey. A população de $L$. casei no flan foi maior que $10^{9} \mathrm{UFC} / \mathrm{g}$ durante a vida de prateleira do produto, valor este, maior que o estabelecido para um alimento probiótico pela legislação brasileira. L. casei mostrou-se relativamente resistente às condições simuladas do trato gastrointestinal avaliadas neste trabalho, uma vez que apesar de sua população ter sido reduzida durante os testes in vitro, esta manteve-se acima de $10^{6} \mathrm{UFC} / \mathrm{g}$. O flan de chocolate mostrou-se um excelente alimento para a introdução de microrganismos probióticos, especialmente $L$. casei, uma vez que observou-se altas populações no produto, mesmo após os testes de resistência in vitro simulando parte do processo digestivo humano.

Palavras-chave: Microrganismos probióticos, sobremesas lácteas, vida de prateleira

\footnotetext{
${ }^{1}$ Discente do curso de Biomedicina, Universidade Norte do Paraná, UNOPAR, Londrina, PR. E-mail: alissonsantana57@gmail.com

${ }^{2}$ Discente do curdo de Nutrição, UNOPAR, Londrina, PR. E-mail: brother_eds@msn.com

${ }^{3}$ Discente do curso de Mestrado em Ciência e Tecnologia do Leite, UNOPAR, Londrina, PR. E-mail: ozinay@hotmail.com

${ }^{4}$ Prof ${ }^{a}$ da Faculdade de Medicina Veterinária e Zootecnia, Universidade Federal do Mato Grosso do Sul, Campo Grande. E-mail: ma_vet2001@yahoo.com.br

${ }_{5}^{5}$ Profs. Pesquisadores do curso de Mestrado em Ciência e Tecnologia do Leite, UNOPAR, Londrina, PR. E-mail: cinthiahoch@ yahoo.com.br; elsahws@hotmail.com; helio.suguimoto@unopar.br; lcalegro@yahoo.com.br

* Author for correspondence
} 


\section{Introduction}

Probiotics are live microorganisms which when administered in adequate amounts provide health benefits to the host (FAO/WHO, 2001; SANDERS, 2003). The Brazilian National Health Surveillance Agency (ANVISA) suggests that a daily serving of beverage or probiotic food ready for consumption provides between $10^{8}$ and $10^{9} \mathrm{CFU}$ of probiotics, ie, this should be the amount of viable microorganisms ingested daily for the purpose of obtaining the benefits of probiotics (ANVISA, 2008).

The addition of probiotics to dairy desserts is a practice that has been investigated. The flan is one of the most traditional Brazilian desserts and shows favorable conditions for the development of probiotic microorganisms, once it presents $\mathrm{pH}$ over 6 and moisture content over 70\%. Considering the popularity of this dessert, the beneficial effects of probiotics and the growing interest of the food industry to develop new probiotic products, the flan seems to be an excellent choice for non-fermented probiotic dairy dessert (CORRÊA; CASTRO; SAAD, 2008).

According to Saad (2006), the main effects of probiotics in foods are to improve lactose digestion in lactose-intolerant individuals; help the balance and stabilization of intestinal flora after antibiotic use; improve the resistance to gastrointestinal colonization by pathogens; and reduce pathogens population by producing organic acids, bacteriocins and other antimicrobial compounds, such as hydrogen peroxide. Furthermore, probiotics can stimulate the immune system, relieve constipation and increase absorption of minerals and vitamins.

Several mechanisms of action of probiotics have been proposed. According to Sleator and Hill (2009) there are three possible mechanisms of action: I) bacteriocins produced by probiotics can lyse invading pathogens; II) probiotic cells can mimic receptors on the surface, preventing the adhesion of pathogens to the host cell membrane,
III) probiotics can neutralize toxins produced by pathogenic microorganisms in the intestine.

According to Fuller (1989) probiotics may also compete with pathogens for nutrients or for binding sites, alter enzymatic activity of these microorganisms and also stimulate the host immunity by increasing the levels of antibodies and the activity of macrophages.

However, to exert some beneficial effects to the host, the probiotic microorganism must necessarily survive the harsh conditions of the human gastrointestinal tract (presence of acids, bile and pancreatic enzymes) and colonize the intestine, at least temporarily, by adhering to the intestinal epithelium (ZIEMER; GIBSON, 1998; SHEEHAN et al., 2007b).

The objective of this study was to evaluate the viability of the probiotic microorganism Lactobacillus casei added to chocolate flan during its shelf life and the survival of the probiotics under simulated conditions of the gastrointestinal tract.

\section{Material and Methods}

\section{Production of chocolate flan}

The probiotic culture used to produce the probiotic flan was Lactobacillus casei (Lpc 37 LYO 50 DCU, Danisco, Dangé, France). The inoculum was prepared the day before the production of dessert by diluting the probiotic culture in milk in a proportion of $2 \%$, followed by refrigerated storage at $4{ }^{\circ} \mathrm{C}$.

The ingredients used to produce the flan were: skimmed UHT milk (Batavo, Teutonia, Brazil), skimmed milk powder (Molico, Nestlé, Araçatuba, Brazil), cream with $25 \%$ fat (Nestle, Araçatuba, Brazil), powdered unflavored gelatin (Oetker, São Paulo, Brazil), sugar (Da Barra, Barra Bonita, Brazil) and soluble cocoa powder (Chocolate do Padre, Nestlé, Araçatuba, Brazil), xanthan gum (Cargill Foods, São Paulo, Brazil). 
The respective amounts are shown in Table 1. After weighing, the ingredients were mixed, with the exception of xanthan gum and probiotic microorganism and heated at $85^{\circ} \mathrm{C}$ in a water bath. The product was cooled to $40{ }^{\circ} \mathrm{C}$ in an ice bath with continuous stirring. Once the temperature of 40 ${ }^{\circ} \mathrm{C}$ was reached, the xanthan gum was added to all formulations. The mixture was homogenized and the inoculum containing the probiotic microorganism (Lactobacillus casei) was added. The flan was homogenized using a mixer (Pérola Plus Britânia) until the temperature of $14{ }^{\circ} \mathrm{C}$ was reached. The product was packed in sterilized plastic cups with a lid, which contained approximately $35 \mathrm{~g}$ of flan.

Table 1. Formulation of probiotic chocolate flan.

\begin{tabular}{lc}
\hline Ingredients & Percent (\%) \\
\hline Skimmed UHT milk & 46.98 \\
Cream (25\% fat) & 28.18 \\
Skimmed milk powder & 1.88 \\
Powdered unflavored gelatin & 1.13 \\
Sugar & 14.09 \\
Cocoa powder & 7.52 \\
Xanthan gum & 0.02 \\
Probiotic culture & 0.20 \\
\hline
\end{tabular}

Source: Elaboration of the authors.

The product was stored at $4{ }^{\circ} \mathrm{C}$ for 15 days to carry out the analyses. The entire experiment was performed in triplicate.

\section{Viability of Lactobacillus casei}

The determination of viability of the probiotic microorganism L. casei in the dessert was performed in the just processed product (day 1) and after 15 days of refrigerated storage at $4{ }^{\circ} \mathrm{C}$. Samples of $10 \mathrm{~g}$ of the product were collected aseptically and homogenized with $90 \mathrm{~mL}$ of $0.85 \%$ saline solution. Subsequent decimal dilutions were prepared using the same diluent and plated on agar DeMan Rogosa-Sharpe (MRS Himedia, Mumbai, India) supplemented with 1\% sorbitol (RAVULA; SHAH, 1998). The colonies were counted after 3 days of incubation at $37{ }^{\circ} \mathrm{C}$ under aerobic conditions. Analyses were performed in duplicate. The results were expressed as colony forming units per gram of flan (CFU / g).

\section{Simulating the gastrointestinal tract conditions}

To verify the resistance of $L$. casei under simulated conditions of the human gastrointestinal tract (RAO; SHIWNARAIN; MAHARAJ, 1989; THANTSHA et al., 2008), a portion of $1 \mathrm{~g}$ of the probiotic flan was added to $9 \mathrm{~mL}$ of sterile solution simulating the stomach acid $(0.08 \mathrm{M} \mathrm{HCl}$ containing $0.2 \% \mathrm{NaCl}-\mathrm{pH} 2.0$ ) and incubated at $37^{\circ} \mathrm{C}$. After $30,60,90$ and $120 \mathrm{~min}$, two aliquots of $1 \mathrm{~mL}$ were withdrawn: an aliquot was used to determine the viability of the probiotic microorganism as described in item 2. The other aliquot was added to $9 \mathrm{~mL}$ of sterile solution containing bile salts $(0.05$ $\mathrm{M} \mathrm{K}_{2} \mathrm{PO}_{4}$ at $\mathrm{pH} 7.4$, plus $0.6 \%$ of bile salts). This step was carried out to study the resistance of the probiotics under simulated conditions of the human intestine. For this, the second aliquot with a solution containing bile salts was incubated at $37^{\circ} \mathrm{C}$ for 150 min. After this time, $1 \mathrm{ml}$ aliquot was collected to verify the viability of the microorganism as described in item 2. 


\section{Statistical analysis}

The results were analyzed by Analysis of Variance (ANOVA) and Tukey's test, both at 5\% significance level $(\mathrm{P}<0.05) \quad($ CALLEGARI-JACQUES, 2003) using Statistica software (STATSOFT, 2000).

\section{Results and Discussion}

The population of $L$. casei on the first day of storage was $10.77 \log \mathrm{CFU} / \mathrm{g}$ (Figure 1). Considering a $100 \mathrm{~g}$ portion of flan, the probiotic population to be ingested is $10^{12} \mathrm{CFU}$, which is above the value recommended by ANVISA, which establishes that a portion of beverage or probiotic food ready for consumption must offer between $10^{8}$ and $10^{9} \mathrm{CFU}$ of probiotics. Thus, this is the dose of probiotics that should be consumed daily to achieve its beneficial effects (ANVISA, 2008).
After 15 days of refrigerated storage, the population of $L$. casei decreased $1.2 \mathrm{log}$ cycles $(\mathrm{P}<0.05)$ (Figures 1 and 2). In spite of the decrease in the number of viable cells, they have always remained higher than the values required by ANVISA for a probiotic food (ANVISA, 2008).

Similar results were observed in several studies, where the survival of probiotic bacteria incorporated into dairy desserts was evaluated.

Corrêa et al. (2008) evaluated the feasibility of probiotic microorganisms (Lactobacillus paracasei and Bifidobacterium lactis) alone or in co-culture in coconut flan stored at $5{ }^{\circ} \mathrm{C}$ for 28 days. The authors found that populations of L. paracasei and B. lactis remained above $7 \log \mathrm{CFU} / \mathrm{g}$ during the entire storage period.

Figure 1. Mean values of population of Lactobacillus casei $(\log \mathrm{CFU} / \mathrm{g})$ in the chocolate flan on the first day of refrigerated storage before and after remaining in solutions that simulate gastric acid (for 30, 60, 90 and $120 \mathrm{~min}$ ) and intestinal bile salts (for $150 \mathrm{~min}$ ).

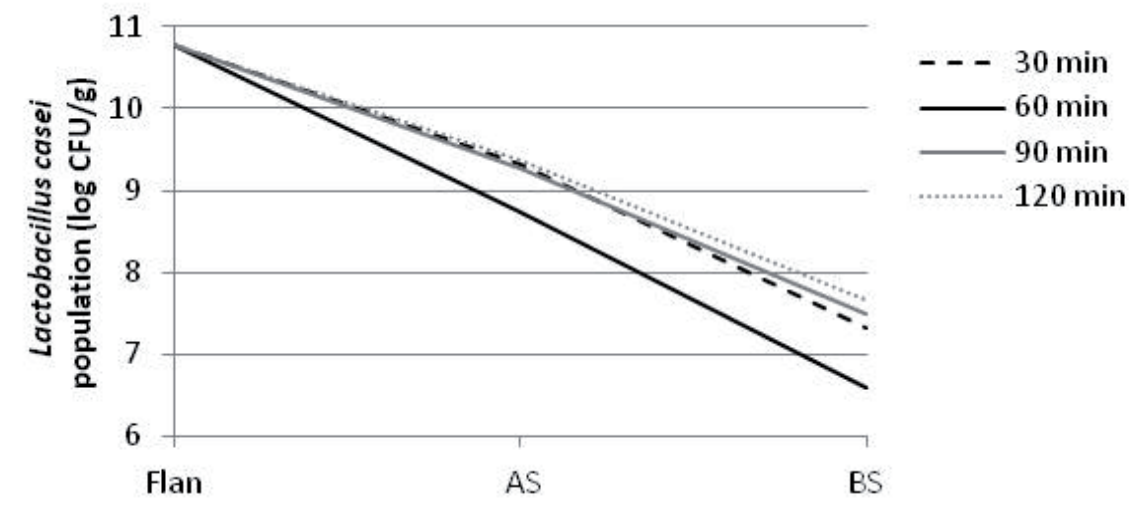

AS $=$ acidic solution, $\mathrm{BS}=$ bile salts.

Source: Elaboration of the authors. 
Figure 2. Mean values of population of Lactobacillus casei $(\log \mathrm{CFU} / \mathrm{g})$ in the chocolate flan on the 15th day of refrigerated storage before and after remaining in solutions that simulate gastric acid (for 30, 60, 90 and $120 \mathrm{~min}$ ) and intestinal bile salts (for $150 \mathrm{~min}$ ).

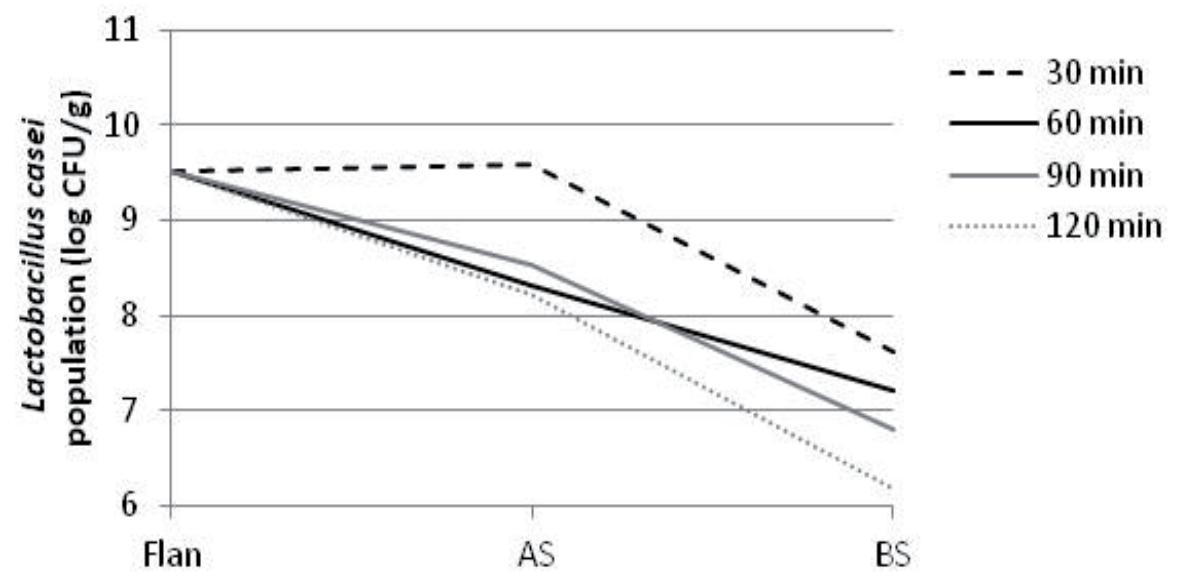

$\mathrm{AS}=$ acidic solution, $\mathrm{BS}=$ bile salts.

Source: Elaboration of the authors.

Helland, Wicklund and Narvhus (2004) evaluated the survival of four probiotic strains (Lactobacillus acidophilus La5 and 1748, Bifidobacterium animalis Bb12 and Lactobacillus rhamnosus GG) on milk puddings and cereals, polydextrose added or not, and found that all microorganisms survived and proliferated in the products, keeping populations between 8 and $9 \log \mathrm{CFU} / \mathrm{g}$.

Similarly, Ozcan et al. (2010) examined the viability of Lactobacillus acidophilus LA-5 and Bifidobacterium bifidum BB-12 in dairy dessert added of rice flour. The authors observed a significant decrease $(\mathrm{P}<0.01)$ in both populations during refrigerated storage at $4 \pm 1{ }^{\circ} \mathrm{C}$ (21 days), but the final population was sufficient to classify the dessert as a probiotic food, remaining up to $6.50 \mathrm{log}$ $\mathrm{CFU} / \mathrm{g}$ for both cultures.

Buriti, Komatsu and Saad (2007) evaluated probiotic mousses (Lactobacillus acidophilus La-5) containing passion fruit juice or pulp or guava pulp. The authors found that the addition of passion fruit, both in the form of juice and pulp is not suitable for probiotic foods once it inhibited the multiplication of L. acidophilus La-5. On the other hand, La-5 populations remained above $6 \log \mathrm{CFU} / \mathrm{g}$ in refrigerated mousses containing guava pulp. In the present study, the cocoa powder added to the flan caused no adverse effects on the viability of L. casei.

Aragon-Alegro et al. (2007) studied probiotic (Lactobacillus paracasei) and symbiotic ( $L$. paracasei and inulin) chocolate mousses. The authors found satisfactory population of $L$. paracase $i$ in two formulations, which remained above $6 \mathrm{log}$ $\mathrm{CFU} / \mathrm{g}$ during 28 days of storage at $5{ }^{\circ} \mathrm{C}$.

Magariños et al. (2008) evaluated the survival of probiotic strains of Lactobacillus casei Shirota and Bifidobacterium animalis subsp. lactis in a milk-based dessert with cranberry sauce. After 21 days of storage, the authors found reductions of $B$. lactis populations, with counts of $1.99 \times 10^{6} \mathrm{CFU} / \mathrm{g}$, whereas L. casei Shirota survived better in the product, featuring population of $2.05 \times 10^{7} \mathrm{CFU} / \mathrm{g}$. The authors concluded that milk-based desserts may be an ideal vehicle for probiotic microorganisms. 
With respect to the resistance to simulated GI tract conditions, after 1 day of storage a significant decrease in the population of $L$. casei was observed $(\mathrm{P}<0.001)$ (Figure 1). However, no differences were observed in populations of $L$. casei $(\mathrm{P}>0.05)$ as compared to the different times of passage by both the acidic and the bile salts solutions, whose populations varied from 8.73 to $9.36 \mathrm{log} \mathrm{CFU} / \mathrm{g}$ and from 6.59 to $7.66 \log \mathrm{CFU} / \mathrm{g}$, respectively. This decrease is probably due to the injuries caused by low $\mathrm{pH}$ to the microorganisms and by the action of bile salts. It is known that probiotics lose viability when placed in acidic environments (DAVE; SHAH, 1997; SHEEHAN et al., 2007a; EL-SHAFEI et al., 2010). In addition, bile is also known as a causative agent of bacterial stress (BEGLEY; GAHAN; HILL, 2005).

In this study, the 15th day of storage presented a reduction of about $1 \mathrm{log}$ cycle in the population of the probiotics in relation to the first day of analysis (Figure 2). After simulating the acidic conditions in the stomach, there was a reduction of the probiotics population $(\mathrm{P}<0.05)$ except for the sample that was removed after 30 min of testing. After contact with the solution containing bile salts, a significant reduction of $L$. casei in all samples was observed $(\mathrm{P}<0.05)$, with populations varying from 6.18 to 7.20 $\log \mathrm{CFU} / \mathrm{g}$. On the 15 th day there was no significant difference in the final probiotics population after exposing the solution simulating stomach acidic (SA) and containing bile salts (BS) $(\mathrm{P}>0.05)$.

It is not known exactly the population capable of surviving after passage through simulated human gastrointestinal systems. However, it is known that the probiotic microorganisms should be resistant to gastric and intestinal conditions, though the maximum reduction acceptable after such tests is not specified. In this study, even after in vitro simulation of the passage through the human GI tract, the population of L. casei was over $10^{6}$ $\mathrm{CFU} / \mathrm{g}$. This result may be associated to the matrix used (flan), once the food matrix plays an important role in protecting the probiotic microorganisms when subjected to digestion. Moreover, the buffering capacity of the milk may help to protect the probiotics against the action of gastrointestinal environments (SIRÓ et al., 2008).

Lower populations were verified by Chaves et al. (2009), who evaluated the resistance of $L$. acidophilus in "Coalho" cheese made with goat's milk and stored for 15 days. The authors found a final population of $3.24 \mathrm{log}$ CFU/g after simulation of the passage through the GI system, showing that the strain (L. acidophilus) was sensitive to bile salts.

Buriti, Castro adn Saad (2010) studied the effect of refrigeration, freezing and replacement of milk fat by inulin and whey protein concentrate on the viability of $L$. acidophilus La-5 and its resistance to enteric simulated gastric conditions in symbiotic guava mousse. The authors observed that after 14 days of refrigerated storage the survival of the probiotic microorganism decreased considerably during testing in vitro and the supplementation with inulin and whey protein concentrate provided no protection to the probiotic bacteria.

\section{Conclusions}

The population of L. casei found in the flan during its shelf life was more than $10^{9} \mathrm{CFU} / \mathrm{g}$, which were above the values required by Brazilian legislation for probiotic foods. The strain of $L$. casei was relatively resistant to simulated gastrointestinal conditions tested in this study. After passing through the simulated gastrointestinal tract, the probiotic population decreased. Yet, they still remained above $10^{6} \mathrm{CFU} / \mathrm{g}$.

Thus, it can be said that the chocolate flan may be an excellent food matrix for adding probiotic microorganisms especially $L$. casei, since high populations were observed in the product after the tests simulating the digestive process in the human gastrointestinal tract. 


\section{Aknowledgements}

The authors thank Cargill and Danisco for the donation of probiotic microorganism L. casei and xanthan gum, respectively

\section{References}

AGÊNCIA NACIONAL DE VIGILÂNCIA SANITÁRIA - ANVISA. Comissões tecnocientíficas de assessoramento em alimentos funcionais e novos alimentos. Alimentos com alegações de propriedades funcionais e ou de saúde, novos alimentos/ingredientes, substâncias bioativas e probióticos: lista das alegações aprovadas. 2008. Disponível em: <http://www.anvisa. gov.br/alimentos/comissoes/tecno_lista_alega.htm>. Acesso em: 20 set. 2011.

ARAGON-ALEGRO, L. C.; ALEGRO, J. H. A.; CARDARELLI, H. R.; CHIU, M. C.; SAAD, S. M. I. Potentially probiotic and synbiotic chocolate mousse. LWT - Food Science and Technology, Oxford, v. 40, n. 4, p. 669-675, 2007.

BEGLEY, M.; GAHAN, C. G. M.; HILL, C. The interaction between bacteria and bile. FEMS Microbiology Reviews, Malden, v. 29, n. 4, p. 625-651, 2005.

BURITI, F. C. A.; KUMATSU; T. R.; SAAD, S. M. I. Activity of passion fruit (Passiflora edulis) and guava (Psidium guajava) pulps on Lactobacillus acidophilus in refrigerated mousses. Brazilian Journal of Microbiology, São Paulo, v. 38, n. 2, p. 315-317, 2007.

BURITI, F. C. A.; CASTRO, I. A.; SAAD, S. M. I. Viability of Lactobacillus acidophilus in synbiotic guava mousses and its survival under in vitro simulated gastrointestinal conditions. International Journal of Food Microbiology, Torino, v. 137, n. 2-3, p. 121-129, 2010.

CALLEGARI-JACQUES, S. M. Bioestatística: princípios e aplicações. São Paulo: Artmed, 2003.

CHAVES, G. M.; LISERRE, A. M.; ZACARCHENCO, P. B.; SANTOS, K. M. O.; MORENO, I. Simulação do sistema gastrointestinal humano para avaliação da resistência de probiótico em queijo de coalho com leite de cabra. In: CONGRESSO INTERINSTITUCIONAL DE INICIAÇÃO CIENTÍFICA, 3., 2009, Campinas. Anais... Campinas: ITAL: IAC; Jaguariúna: Embrapa Meio Ambiente, 2009. 6 p. 1 CD-ROM.

CORRÊA, S. B. M.; CASTRO, I. A.; SAAD, S. M. I. Probiotic potential and sensory properties of coconut flan supplemented with Lactobacillus paracasei and Bifidobacterium lactis, during shelf life of the product.
International Journal of Food Science and Technology, Oxford, v. 43, n. 9, p. 1560-1568, 2008.

DAVE, R. I.; SHAH, N. P. Viability of yoghurt and probiotic bacteria in yoghurts made from commercial starter cultures. International Dairy Journal, Edmonton, v. 7, n. 1, p. 31-41, 1997.

EL-SHAFEI, K.; TAWFIK, N. F.; DABIZA, N. M. A.; SHARAF, O. M.; EFFAT, B. A. In vitro assessment of gastrointestinal viability of potentially probiotic Lactobacilli. Journal of American Science, Michigan, v. 6, n. 11, p. 357-367, 2010.

FOOD AND AGRICULTURE ORGANIZATION OF THE UNITED NATIONS; WORLD HEALTH ORGANIZATION. FAO/WHO. Evaluation of health and nutritional properties of probiotics in food including powder milk with live lactic acid bacteria. 2001. Disponível em: <ftp://ftp.fao.org/es/esn/food/ probioreport_en.pdf.>. Acesso em: 03 fev. 2005.

FULLER, R. Probiotics in man and animals. Journal of Applied Bacteriology, Oxford, v. 66, n. 5, p. 365-378, 1989.

HELLAND, M. H.; WICKLUND, T.; NARVHUS, J. A. Growth and metabolism of selected strains of probiotic bacteria in milk - and water-based cereal puddings. International Dairy Journal, Edmonton, v. 14, n. 11, p. 957-965, 2004.

MAGARIÑOS, H.; CARTES, P.; FRASER, B.; SELAIVE, S.; COSTA, M.; FIGUEROLA, F.; PIZARRO, $\mathrm{O}$. Viability of probiotic micro-organisms (Lactobacillus casei Shirota and Bifidobacterium animalis subsp. lactis) in a milk-based dessert with cranberry sauce. International Journal of Dairy Technology, Huntingdon, v. 61, n. 1, p. 96-101, 2008.

OZCAN, T.; YILMAZ-ERSAN, L.; AKPINARBAYIZIT, A.; SAHIN, O. I.; AYDINOL, P. Viability of Lactobacillus acidophilus LA-5 and Bifidobacterium bifidum BB-12 in rice pudding. Mljekarstvo, Croatia, v. 60, n. 2, p. 135-144, 2010.

RAO, A. V.; SHIWNARAIN, N.; MAHARAJ, L. Survival of microencapsulated Bifidobacterium pseudologum in simulated gastric and intestinal juices. Canadian Institute of Food Science and Technology, Toronto, v. 22, n. 4, p. 345-349, 1989.

RAVULA, R. R.; SHAH, N. P. Selective enumeration of Lactobacillus casei from yogurth and fermented milk drinks. Biotechnology Techniques, Dordrecht, v. 12, n. 11, p. 819-822, 1998.

SAAD, S. M. I. Probióticos e prebióticos: o estado da arte. Revista Brasileira de Ciências Farmacêuticas, São Paulo, v. 42, n. 1, p. 1-16, 2006. 
SANDERS, M. E. Probiotics: considerations for human health. Nutrition Reviews, New York, v. 61, n. 3, p. 9199, 2003.

SHEEHAN, V. M.; ROSS, P.; FITZGERALD, G. F. Assessing the acid tolerance and the technological robustness of probiotic cultures for fortification in fruit juices. Innovative Food Science \& Emerging Technologies, Haverlee, v. 8, n. 2, p. 279-284, 2007 a.

SHEEHAN, V. M.; SLEATOR, R. D.; HILL, C.; FITZGERALD, G. F. Improving gastric transit, gastrointestinal persistence and therapeutic efficacy of the probiotic strain Bifidobacterium breve UCC2003. Microbiology,Paris, v. 153, n. 10, p. 3563-3571, 2007 b.

SIRÓ, I.; KÁPOLNA, E.; KÁPOLNA, B.; LUGASI, A. Functional food. product development, marketing and consumer acceptance - a review. Appetite, Durham, v. 51, n. 3, p. 456-467, 2008.
SLEATOR, R. D.; HILL, C. Rational design of improved pharmabiotics. Journal of Biomedicine and Biotechnology, New York, v. 2009, n. 2009, p. 87-2752, 2009.

STATSOFT, Inc. Statistica for windows: computer program manual. Tulsa, OK: StatSoft, Inc. 2000.

THANTSHA, M. S.; CLOETE, T. E.; MOOLMAN, F. S.; LABUSCHAGNE, P. W. Supercritical carbon dioxide interpolymer complexes improve survival of $B$. longum $\mathrm{Bb}-46$ in simulated gastrointestinal fluids. International Journal of Food Microbiology, Torino, v. 129, n. 1, p. 88-92, 2008.

ZIEMER, C.; GIBSON, G. R. An overview of probiotics, prebiotics and synbiotics in the functional food concept: perspective and future strategies. International Dairy Journal, Edmonton, v. 8, n. 5-6, p. 473-479, 1998. 